\title{
SETTLEMENT AND ACCULTURATION IN THE IRISH SEA REGION DAVID GRIFFITHS
}

This impressive range of papers provides the opportunity to explore some geographically wide-ranging themes whilst remaining rooted in the 'hard' detail of locally-specific research strategies. That the Irish and western British research scene is a healthy and productive counterpart to work elsewhere is amply demonstrated elsewhere in this volume by (amongst others) Mark Redknap and Patrick Wallace. In contrast to some recent studies of the Danelaw, $\{1\}$ however, there has been less synthetic coverage to the west. Widening the perspective from the individual archaeological sites to look at regional patterns of settlement, identity and assimilation is still a challenge: possibly a risky one as the threads of analysis linking the still-sparse archaeological evidence become ever longer and thinner. For example, we are as yet counting the archaeological sites indicating unambiguously Viking rural settlement in Ireland and western Britain in single figures (see also Nick Higham, this volume). The challenge should not be shirked for that reason, indeed it makes it more necessary. Rather than presuming to offer generalised conclusions to other relevant papers presented here, I prefer to run through some ideas about the Scandinavian settlement of the Irish Sea region which originally formed a large part of my doctoral thesis, but which I have taken this opportunity to update and re-think. $\{2\}$ 
I might add that this paper was also conceived as a response to the outpouring of recent books and articles about the Danelaw: the Viking settlements of western Britain and Ireland have been comparatively neglected in terms of newer approaches to studying settlement and identity. The work of John Hines has provided a beacon in archaeological and philological literature to those interested in the culture, language and identity of the peoples of Early Medieval Britain. \{3\} James Barrett's study of Viking-age Scotland presented here is also most welcome and rehearses some essential concepts in the literature of the wider anthropological debate about ethnicity which would be superfluous for me to repeat. As a counterpart focused geographically to the south of Barrett's area, this paper aims to show that the Irish Sea region forms an equally interesting case-study, not so much of the 'event' but of the process of Viking settlement.

\section{THE IRISH SEA REGION}

The Irish Sea region is a semi-landlocked maritime zone, once called the 'British Mediterranean' by the Edwardian Oxford geographer Halford Mackinder. It is now more fashionable than it once was to treat archaeology in a maritime zone as an inter-related cultural network. The recent book by Barry Cunliffe Facing the Ocean has reinvigorated the idea of seaborne communication and trade as a dynamic in forming identities in prehistoric and early historic Europe, reviving earlier ideas on this theme (such as those of E.G. Bowen). $\{4\}$ When Viking raiders first enter our historical consciousness in this region, off the coast of Antrim in 795, they were involving themselves in a part of the world which was extremely fluid in terms of identity and territorial allegiance and had 
been for many centuries; this will be obvious to anyone who has studied the ebb and flow of Irish influence in Wales and Scotland; the Anglians and Britons in southern Scotland and northern England, and the Roman influence on the region: this is truly a place where the binary concept of "native" and "immigrant" are wholly inadequate to explain the complexity of the situation.

The chronology and archaeological distribution of the early Viking presence in the Irish Sea region has been very clearly laid out in two recent articles by James GrahamCampbell. $\{5\}$ The historical framework provided largely by the Irish annals has given us a structure within which to locate the phases of Viking influence in the Irish Sea region. The details of the raids of the 790s, the movement around Ireland during the ninth century of Viking armies, and the establishment of longphorts in Dublin, Annagassan and elsewhere have all been dealt with in all their complexity by Donnchadh Ó Corráin, Dáibhí Ó Cróinín and other writers. $\{6\}$ The great Viking cemetery of Kilmainham/ Islandbridge a short distance up-river from the later site of tenth-century Dublin, $\{7\}$ has helped to give rise to a general view of the ninth-century Viking settlements in Ireland as definitively 'Scandinavian' in material culture terms. Notwithstanding the deposition in grave contexts in Ireland of classically Viking weapons such as these, the emergence of a hybrid Hiberno-Norse population (the Gael-Gaedhil) must already have been well under way by the mid-ninth century; the wide geographical scope of the Vikings in Ireland at this time must surely have resulted in an admixture of Irish followers which changed forever the 'Scandinavian-ness' of the leaders' cultural and linguistic repertoire. 
The expulsion of the Norse from Dublin in 902 and their subsequent 'arrival' as settlers on the eastern (British) seaboard of the Irish Sea has been almost universally seen as the context for the Viking settlement of north-west England and probably also parts of southwest Scotland. Historically this is supported by the only detailed account of such a Viking episode, namely the story described in the Irish Fragmentary Annals, and almost certainly corroborated by the Welsh annals, of the Hiberno-Norse chieftain Ingimund and his followers' unsuccessful attempt in 902-3 to settle in North Wales followed by a more successful attempt in western Cheshire, $\{8\}$ now recognised as the northern half of the Wirral peninsula.

The presence of furnished mound burials with Scandinavian-style objects, including at least one cremation at Hesket in the Forest, Aspatria, Ormside and Rampside in Cumbria and Claughton Hall in northern Lancashire $\{9\}$ are parallelled by the dramatic Viking grave evidence from the Isle of Man, such as at Ballateare, Peel Castle and Balladoole, $\{10\}$ where a ship setting was superimposed over an earlier Christian cemetery (which is graphic evidence in this case of an explicit statement of difference, albeit in a situation of burial continuity, a fact which is less often stressed).

Burial is, of course, as much a social and political statement intended for the living as a religious statement for the dead: what we may be seeing at Kilmainham and also in some cases up to a century later on the Isle of Man and in Cumbria, is a conscious display of cultural conservatism within the funerary context designed to establish a presence in the landscape of Norse-dominated territories, from which a fast-changing cultural admixture 
amongst the living population could be convinced of the historical legitimacy of their leaders' power.

CHARACTERISING VIKING SETTLEMENT

From the early to mid-tenth century onwards, the standard picture tells us, the Vikings quickly abandoned paganism and were assimilated into the existing populations, to the extent that their influence is only dimly visible in terms of political and territorial structures by the time of the Norman conquest, and hardly visible at all in material culture terms. Only the place-names, this spread of dots on the map, stand as a near-universal and therefore confusing memorial to a people who left little else as evidence of their presence. As rightly pointed out in some of the recent Danelaw studies, we have been preoccupied with a rather sterile debate about numbers of migrants, the elite/mass migration hypotheses, which are couched in largely unanswerable terms given the limitations of the evidence and the much-commented upon disjuncture between material culture and place-name approaches.

The place-name map (fig. 1) is what we are left with after several centuries of cultural, territorial and linguistic adjustment and re-adjustment, and examples such as those -by place-names in the Eden valley in Cumbria remarked upon by Brian Roberts, which do not date to before the $12^{\text {th }}$ century, must alert us to the dangers of simplistically correlating place-name distributions with primary areas of Viking settlement. $\{11\}$ Place- 
names are of course notoriously hard to date. The over all place-name map is, if anything, the end-product of the cultural and linguistic processes set in train by the Viking presence. Within the place-name distribution however, when combined with historical evidence for territorial acquisition and the presence of particular types of archaeological material, it is possible to suggest a number of smaller and territorially-restricted areas of Viking influence which have something to tell us about the extent of the Viking presence in the landscape in the late ninth and tenth centuries.

The mechanisms by which the Vikings acquired land need a closer look. The Ingimund episode was an example of acquisition by negotiation with Aethelflede of Mercia, despite the subsequent failed attack by Ingimund's group on Chester. I have argued elsewhere that the activities of disparate and mostly relatively small bands of Hiberno-Norse Vikings were not the primary strategic concern of Mercia and Wessex in the period 900925; the annexation of former Northumbrian territory and border problems with the Welsh explain much of the strategy of the Anglo-Saxon authorities in the North West at this time. $\{12\}$ There seems to have been little objection to the establishment, apparently by peaceful agreement, of small Viking-dominated settlement enclaves. Ingimund's presence in the Wirral is one such enclave. In Lancashire, Amounderness, a probable preViking multiple estate argued by Gillian Fellows-Jensen on place-name grounds to represent a Viking lordship in the early tenth century, was recorded in a grant of Athelstan as having been purchased from the 'pagans'. $\{13\}$ Further evidence for 'consensual' or 'administrative' land-transfer is found in the name Copeland (ON kaupa land - bought land) an area of dense Norse influence on the western coast of Cumbria, 
isolated from the English interior by the Lake District mountains but within clear sight of the Isle of Man.

Angus Winchester's study of Viking settlement in Cumbria published in 1985 characterised the initial Viking presence as an aristocratic takeover. $\{14\}$ The existing north and west Cumbrian lowland estates held tenurially by the due of both 'cornage' and 'seawake' and which are characterised by a mixture of Celtic, English and Norse placenames, were argued by Winchester to have been the earliest lands taken over by the Vikings. Other estate foci in Cumbria held by Cornage alone tend to be further inland and on poorer land, which he interpreted as secondary colonisation following the establishment of the main Scandinavian estate centres on the coast. The Viking settlement on the Isle of Man can be closely compared in many aspects to the Cumbrian situation. The distribution of Scandinavian names in by-is predominantly coastal and densest in the low northern coastal plain of the island, particularly in the parishes of Bride and Jurby. Paul Reilly's work on the relative distribution of the quarterland boundaries and the grave monuments on the coastal strip found no statistical support for the earlier theory of Basil Megaw that the grave distribution predated the arrangement of the quarterland boundaries: the consequent conclusion was that the Vikings took over existing territorial units. $\{15\}$

Richard Oram's recently published work on Galloway has lent even more support to the idea that the Viking settlements in this part of the Irish Sea region were initially small scale and accommodated within existing territorial structures. $\{16\}$ Two areas in 
particular stand out as localised concentrations. A small area on the Kirkcudbright coast around the estuary of the River Dee, where a sword, ringed pin and jet bead from a St Cuthbert's churchyard in Kirkcudbright suggest a furnished Viking grave; $\{17\}$ and a dense but localised collection of place-names indicate a Norse enclave. Further to the west on the southern Machars peninsula, Oram has drawn attention to the distribution of Scandinavian names, including the probable Viking landholdings of Sorbie and Bysbie, which he dates to the tenth century and suggests were accommodated within the territorial remit of the monastery of Whithorn. In addition, there may also have been small enclaves on the Rhins peninsula of western Galloway, such as around Kirkcolm, where a tenth-century Viking-style carved stone (the 'Kilmorie Cross') found close to the sheltered embayment on Loch Ryan known as the 'Wig' (ON vikr - bay) suggests a Viking-age presence alongside this strategic natural harbour on the sea route north to the isles.

John Bradley's work on Ireland suggests that, whatever the [apparently shortlived] territorial impact of the ninth-century longphorts, during the tenth century and certainly by the time that the process of urbanisation in Dublin, Waterford, Wexford, Cork and Limerick had become extensive, each of the Hiberno-Norse towns was located within a small but distinct territorial enclave. $\{18\}$ These may have had very small origins in the second decade of the tenth century, but gradually expanded by (by alliance, conquest and possibly purchase) to form a viable urban hinterland. 
If I can put forward this modification of the place-names map (fig. 2) as a rough suggestion of the 'primary' Viking landholdings before about 950: we are looking at a series of small distinct 'pockets' of Viking settlement; almost certainly 'elite' in terms of leadership but with an admixture of people who were from Gaelic, Anglian, British, Danish and perhaps in some cases even more obscure origins who had chosen for whatever reason to throw their lot in with the descendants of the Norwegian Vikings from the longphorts. We must also assume that the inhabitants were a mixture of those who had recently arrived, and those who had been there all the time but whose overlord had just changed whether they liked it or not.

\section{LANDED POWER AND SYMBOLIC DISPLAY}

The Viking settlement areas are characterised by evidence for territorial distinctiveness: in the case of (famously) the Isle of Man, but also Dublin, Wirral, West Derby and Dumfriesshire the place-name evidence for Thing sites (also with a possible thing-mound preserved at Little Langdale, Cumbria) confirms a special Norse dimension to local administration.

The grave sites of the Isle of Man and Cumbria are characterised by spectacular mound burial, and there is evidence of this also taking place in Dublin, close to the Thing site known as the Thingmote (levelled in 1685) by present-day college green (an area arguably a distinct elite focus east of the River Poddle, just across from the most built-up 
area of the Viking town). $\{19\}$ One of the remarkable aspects of the Manx burials is their very late date for apparently 'pagan' Viking monuments. On the basis of coin evidence from the grave, Graham-Campbell has dated the so-called Pagan Lady of Peel to no earlier than the 940's. $\{20\}$ The Ballateare, Balladoole and Cronk Mooar burials excavated by Gerhard Bersu in during the second world war $\{21\}$ all had examples of metalwork which could be described as Irish Sea Norse in origin, rather than true Scandinavian. These burials, in fact, are a very 'Irish Sea' theme which ultimately harks back to Norwegian burial practice.

In the Isle of Man, Cumbria, Lancashire and the Wirral, the areas of 'primary' early to mid-tenth century Norse settlement as suggested above are also characterised by very visible displays of stone sculpture at church sites, with free standing crosses, large slabs and hogbacks representing the most common themes. Given the surprisingly late date of the mound burials: we are looking at a situation where some of the earlier stone sculpture (Richard Bailey dates several of the Cumbrian examples to the 940s $\{22\}$ ) may well be near-contemporary. This situation speaks hardly of a long-term diffusion of cultural change in a quiet backwater: but more of a very dynamic and pro-active display of symbolic lordship in the early to middle tenth century, involving 'conservative' elements (the mound burials) and forward-looking elements more in tune with the contemporary tradition of the host country (namely the sculpture). Where the physical manifestations of power do not exist, because settlement has been a recent or concurrent development; create them fast! 
My period as a visiting researcher in Troms $\varnothing$, Norway gave me the chance to research the geography and symbolism of Viking-age landed power. In northern Norway, for example, distinct chiefdom foci are present at strategic points within the landscape. $\{23\}$ These are characterised by large mound burials and boat nausts, thing sites, and 'tunanlegg' or 'court sites' of buildings arranged in sub-circular formation at meeting places (fig. 3), such as the example recorded by Harald Egnaes Lund on Bjarkøy south of Troms $\varnothing$; and increasingly by evidence for participation in long-distance trade with the Viking world. $\{24\}$ These observations led me to propose in my $\mathrm{PhD}$ thesis that the Norwegian chiefdom model was the template, albeit a derivative one by the tenth century, around which the Norse leaders in the Irish Sea region constructed the outward manifestation of their rule. When arriving with a multifarious following on a foreign shore in order to take over the lives and lands of yet more people, the rapid imposition of familiar symbols of chiefly authority was a way of creating a baseline from which the accommodation of new allegiances and the promotion of new identities could then follow (perhaps like the construction of other sometimes anachronistic symbols in other socalled 'colonial' situations).

The Gosforth Cross in Copeland, Cumbria, is an oft-quoted example of the clear association of Norse mythological imagery with a Christian message (or perhaps just a 'modern' message in the context of the tenth-century). The spread of circle-headed crosses across the Cumbrian coastal areas, the Isle of Man, and into the Wirral is more than just a wave of passive influence. I would agree with Hines, Barrett and others that patterns of 'instrumentalist' acculturation, the active promotion of carefully combined 
cultural messages in order to create a new and more universal cultural context, are a characteristic of the Viking period, and can be seen very clearly in the sculptural repertoire. Stone sculpture has the obvious advantage of being publicly visible, territorially rooted and associated with a clear patronage.

But this process can arguably also be seen in metalwork (and by implication, other artefacts of less durable material such as wood, bone, ivory etc.). The emergence of a characteristically 'Irish Sea' style of metalwork in the tenth century including roundel decorated strap ends, hexagonal bronze bells and lobe-headed pins was a theme which I touched on in my thesis, and I am glad to see that other scholars have also made something of this idea. $\{25\}$ Surely the point to draw out of all this is that the leading Vikings of this region were aware of their cultural roots and derived much of their legitimacy from very publicly re-playing certain backward-looking themes; but they were also infinitely flexible, innovative and capable of very a pro-active stance when seeking to create a unified following in their new landholdings. This was a highly fluid cultural situation; the 'Norwegian' settlers in north-west England in the early tenth century had already been substantially influenced by ninth-century cultural change experienced in Ireland, Scotland and elsewhere.

The Wirral Peninsula (fig. 4), has been the focus of much of my thinking on these matters, (partly because I myself am a product of the area's Anglo-Scando-Welsh mixed lineage!): and I would argue that all of the themes I have mentioned are present here to some degree. As the location of the only historical Hiberno-Norse migration, it has a 
special resonance, and the probable boundaries of the Viking enclave can still be traced in the parish structure. There is a substantial collection of sandstone Viking-age sculpture from the peninsula; a major centre being at St. Bridget's Church, West Kirby. Margaret Gelling recently suggested that there were two early enclaves: the north west of the peninsula and also a small concentration around the south bank of the Mersey estuary near Helsby. $\{26\}$ Across the Mersey in West Derby, Scandinavian settlement was at least as dense, and like the Wirral had its own 'Thingwall' place-name. There was also an enclave of Scandinavians within the burh of Chester, which was the major English trading port in the Irish Sea region during the tenth century. Notwithstanding the local independence of the Norse settlements in Wirral and West Derby; a Norse merchant presence within Chester speaks more of tolerance, intermingling and mutual advantage rather than the ethnic battle-lines so beloved of an earlier generation of historians.

The ancient coastal trading site of Meols on the north Wirral coast, which goes back to the pre-Roman period, was reinvigorated in the tenth century and many of the object types characteristic of the Hiberno-Norse world are represented here along with AngloSaxon coins, strap ends, hooked tags and pins. $\{27\}$ Recent research on the collections by myself and Robert Philpott has re-assigned (in this case with the assistance of Patrick Ottaway) some of the miscellaneous ironwork found by antiquarians on the eroding coastline in the winter of $1877-8$ to a probable Viking grave context, including a shield boss, an axehead, a sword and a deliberately-bent spearhead. 
Mark Redknap's work at Llanbedrgoch in Anglesey, where I helped him excavate two Viking-age long-houses in the 1996 - 99 seasons, has begun to revolutionise our understanding of the Vikings in Wales. With a Viking grave nearby at Benllech, a hoard of silver arm-rings and various single finds, examples of stone sculpture at Penmon and of course the settlement itself with its strong artefactual parallels with Meols, Peel Castle, Chester and Dublin, $\{28\}$ eastern Anglesey bears all the hallmarks of an area of smallscale pockets of Viking settlement accommodated within the existing Welsh landscape.

Another furnished grave on the north Welsh coast was found in 1932 at Talacre, at the mouth of Dee estuary. $\{29\}$ Like the Benllech grave prior to Dr Redknap's discoveries, this has been assumed to be an isolated coastal example of little wider significance. However, this north-eastern corner of Flintshire, with its smattering of Viking placenames, deserves a closer look. In the Domesday Book of 1086, this area was within the disputed Cheshire border hundred of Atiscros, known to the Welsh by its more ancient name of Tegeingl. Following the establishment of the English outpost at Cledemutha (Rhuddlan) in 921, the area changed hands between the English and Welsh several times up to and beyond the Norman Conquest. North of the line of Wat's Dyke, where the land was unhidated and therefore less integrated into Domesday Cheshire, lies the township of Whitford. At a minor crossroads, well away from any church, stands one of the greatest examples of Viking-age stone sculpture in Wales, Maen Achwyfan. A freestanding circleheaded cross in red Cheshire sandstone, it is decorated with T-frets, dense plaitwork and figural imagery which confirm strong artistic links with the Cheshire and Isle of Man groups of crosses. $\{30\}$ Nancy Edwards's reappraisal confirms a probable tenth-century 
date and suggests a connection to contemporary or later stones from nearby Meliden and Dyserth, also in this small portion of temporarily-English land in Wales.

Usually regarded as being in a puzzling location, this stone has been neglected in discussions of settlement. However, it represents a very dramatic statement of lordship and patronage. Was this a wholly new development in this little-known location?; my research would suggest otherwise. Whilst this landscape has yet to be surveyed in detail for likely settlement sites, there are four large and so far poorly-understood tumuli or grave mounds in close proximity to Maen Achwyfan.\{31\} One was reported to have produced a number of undated 'skulls and carcasses' when dug into in the $17^{\text {th }}$ century; the other three are undisturbed. Given the closely-bounded nature of the Scandinavian settlements outlined above, and the presence of mound burial elsewhere, this location could represent a new focus of interest.

To search for a 'direct' Scandinavian presence such as that possibly represented (almost uniquely so far in this region) by the Kilmainham/ Islandbridge cemeteries, and to judge the Viking influence by such an unadulterated colonial standard, was always bound largely to end in disappointment and a failure to appreciate the true potential of the evidence we do have. Rural settlements are a case in point; the absence of obvious soapstone-using, bow-sided longhouse-dwelling communities, south of the northern and western isles of Scotland, is an indication of the Vikings' rapid adaptation to new cultural dynamics rather than a large lacuna in the evidence with all its negative connotations for future research prospects. True, we are not dealing with large numbers of settlers by the 
standards of later times, but our quest to understand the identity of the Vikings in western Britain and Ireland must recognise that this was almost mercurial in its fluidity, as it responded to - and was actively modified in order to influence - the winds of political, territorial and economic opportunity. The occasional display of conservative Scandinavian cultural traits visible in the tenth-century Irish Sea region must be seen in this context: a pragmatic series of actions which can only be readily understood when taken together with other contemporary and near-contemporary developments. Fundamentally an active part of their own tenth-century present rather than merely a passive reflection of an older homeland past, the intriguing distribution of the mound burials, stone sculpture assemblages and the insular Viking metalwork must be the starting point, rather than the somewhat puzzling conclusion, to our inquiry.

1. J. Graham-Campbell, R. Hall, J. Jesch, D. Parsons, Vikings and the Danelaw, Select Papers from the Proceedings of the Thirteenth Viking Congress (Oxford, 2001); D. Hadley, Scandinavian Settlement in the Northern Danelaw (Leicester, 2000); purporting to be more geographically wide-ranging but also Danelawcentred is: D. M. Hadley and J.D. Richards, Cultures in Contact: Scandinavian Settlement in England in the Ninth and Tenth Centuries (Turnhout, 2000).

2. D. Griffiths, Anglo-Saxon England and the Irish Sea Region, AD 800-1100, Unpublished $\mathrm{PhD}$ thesis (Department of Archaeology, University of Durham 1992); Publication of updated version in preparation (BAR British Series, Oxford). 
3. e.g. J. Hines, 'Scandinavian English: a creole in context', in P.S. Ureland and G. Broderick (eds.) Language contact in the British Isles: Proceedings of the eighth language symposium on Language Contact in Europe (Tübingen, 1991), 403-27.

4. B. Cunliffe, Facing the Ocean (Oxford, 2001); D. Moore (ed.) The Irish Sea Province in Archaeology and History (Cardiff, 1970).

5. J. Graham-Campbell, 'The Irish Sea vikings: raiders and settlers' in T. Scott and P. Starkey (eds.) The Middle Ages in the North-West (Oxford, 1995), 59-83; 'The Early Viking Age in the Irish Sea Area' in H. B. Clarke, M. Ní Mhaonaigh, R. Ó Floinn (eds.) Ireland and Scandinavia in the Early Viking Age (Dublin, 1998), 104-30.

6. D. Ó Corráin, Ireland before the Normans (Dublin, 1972); D. Ó Croínín, Early Medieval Ireland 400-1200 (London, 1995).

7. E. O'Brien, 'The Location and Context of Viking burials at Kilmainham and Islandbridge, Dublin' in H.B. Clarke et al., op. cit. in note 5, 203-221.

8. F.T. Wainwright, 'Ingimund's Invasion', Eng. Hist. Rev. 63 (1948), 145-69.

9. For an overview, see B.J.N. Edwards, Vikings in north-west England (Lancaster, 1998).

10. J. Graham-Campbell, op. cit. in note 5; G. Bersu and D.M. Wilson, Three Viking Graves in the Isle of Man (London, 1966); D.M. Wilson 'Scandinavian Settlement in the North and West of the British Isles: An Archaeological Point of View' Trans. Roy. Hist. Soc. 26, 5 ser (1976), 95-114; for an alternative perspective see S. Tarlow, 'The dread of something after death, violation and desecration in the 
Isle of Man in the tenth century', in J. Carman (ed.) Material Harm (Glasgow, 1997), 133-42.

11. B.K. Roberts, 'Late - by Names in the Eden Valley, Cumbria' Nomina XIII (198990), 25-40.

12. D. Griffiths, 'The North West Frontier' in N.J. Higham and D. Hill (eds.) Edward the Elder, 899-924 (London, 2001), 167-87.

13. G. Fellows-Jensen, 'Amounderness and Holderness' in L. Peterson et al. (eds.) Studia Onomastica, Festskrift til Thorsten Andersson 23 Feb. 1989 (Stockholm, 1989), 86-94; G. Fellows-Jensen, 'Scandinavian Place-Names of the Irish Sea Province', in J. Graham-Campbell (ed.) Viking Treasure from the North West, the Cuerdale Hoard in its Context (Liverpool, 1992), 31-42.

14. A.J.L. Winchester,' The Multiple Estate: A Framework for the Evolution of Settlement in Anglo-Saxon and Anglo-Scandinavian Cumbria' in J.R. Baldwin and I.D. Whyte (eds.) The Scandinavians in Cumbria (Edinburgh, 1985), 89-102.

15. P. Reilly, Computer Analysis of an Archaeological Landscape: Medieval Land Divisions in the Isle of Man (BAR British Series 190, Oxford, 1988).

16. R.D. Oram, 'Scandinavian settlement in south-west Scotland with a special study of Bysbie' in B. Crawford (ed.) Scandinavian Settlement in Northern Britain (Leicester, 1995) 127-40.

17. J.G. Scott, 'A note on the Viking settlement in Galloway' Trans. Dumfriesshire and Galloway Natur. Hist. Antiq. Soc. 58 (1983), 52-5. 
18. J. Bradley 'The Interpretation of Scandinavian Settlement in Ireland', in J. Bradley (ed) Settlement and Society in Medieval Ireland, Studies presented to F.X. Martin O.S.A. (Kilkenny, 1988), 49-78.

19. R. Ó Floinn, 'The Archaeology of the Early Viking Age in Ireland' in H.B. Clarke et al., op. cit. in note 5, 131-65.

20. J. Graham-Campbell, in T. Scott and P. Starkey, op. cit. in note 5, 77.

21. G. Bersu and D. M. Wilson, op. cit. in note 10.

22. R.N. Bailey and R.J. Cramp, 'Cumberland, Westmorland and Lancashire Northof-the-Sands' in R. J. Cramp (ed.) British Academy Corpus of Anglo-Saxon Stone Sculpture, Volume 2 (Oxford, 1988); discussion of circle-headed crosses in R.N. Bailey, Viking Age Sculpture in Northern England (London, 1980), 177-82.

23. O.S. Johansen, 'Vikingene lengst i nord: håløygske høvdingesenter in NordNorge' in H. Bekker-Nielsen and H. Frede-Neilsen (eds.) Beretning fra Syvende Tvarfaglige Vikingesymposium (Odense, 1988), 21-46; B. Myhre 'The Archaeology of the Early Viking Age in Norway', in H.B. Clarke et al. op. cit. in note 5, 3-36.

24. O.S. Johansen and T. Sobstad, 'De Nordnorske Tunanleggene fra Jernalderen', Viking 41 (1977), 9-56.

25. e.g. G. Thomas, 'Anglo-Scandinavian Metalwork from the Danelaw: Exploring Social and Cultural Interaction', in D. M. Hadley and J. D. Richards, op. cit. in note $1,246-9$. 
26. M. Gelling, 'Scandinavian settlement in Cheshire, the evidence of place-names', in B. Crawford, op. cit. in note 16, 187-94; J. McN. Dodgson, 'The Background to Brunanburh', Saga Book of the Viking Society 14 (1957), 303-16.

27. Summary: D. Griffiths, ‘Great Sites: Meols’ British Archaeology December 2001, 20-25.

28. M. Redknap, Vikings in Wales, An Archaeological Quest (Cardiff, 2000).

29. F.G. Smith, 'Talacre and the Viking Grave' Proc. Llandudno, Colwyn Bay and District Field Club 17 (1932), 42-50.

30. N. Edwards, 'Viking Influenced Sculpture in North Wales' Church Archaeology 3 (1999), 5-14.

31. Information from Flintshire (formerly Clwyd) Sites and Monuments Record. 